\title{
PEMANFAATAN SITUS GANDOANG DALAM PEMBELAJARAN DENGAN METODE DISCOVERI LEARNING PADA MAHASISWA PROGRAM STUDI PENDIDIKAN SEJARAH
}

\author{
Wulan Sondarika ${ }^{1}$ \\ Dosen Program Studi Pendidikan Sejarah FKIP-Universitas Galuh Ciamis \\ Jl. R. E. Martadinata No. 150 Ciamis, 46274 Jawa Barat
}

\begin{abstract}
ABSTRAK
Metode discovery dalam pembelajaran sejarah dengan tema situs Gandoang sebagai media pembelajaran bertujuan untuk melatih mahasiswa dalam menganalisis suatu peristiwa masa lampau dan manfaat situs Gandoang sebagai sumber belajar sejarah dan pariwisata lokal. metode penelitian dalam penelitian ini yaitu kualitatif. Penelitian kualitatif adalah prosedur penelitian yang menghasilkan data deskriptif berupa kata-kata tertulis atau lisan dari orang-orang dan perilaku yang diamati. Hasil penelitian bahwa setelah di analisis proses pembelajaran dengan metode discoveri sangat membantu dosen dalam menciptakan suasana belajar yang aktif, edukatif dan menyenangkan serta dapat merangsang siswa untuk berfikir kritis dan kreatif dalam mencari sumber belajar mandiri.
\end{abstract}

Kata Kunci: Situs Gandoang, pembelajaran Discoveri learning

\begin{abstract}
The discovery method in historical learning with the theme of the Gandoang site as a learning medium aims to train students to analyze past events and the benefits of the Gandoang site as a source of learning history and local tourism. The research method in this study is qualitative. Qualitative research is a research procedure that produces descriptive data in the form of written or oral words from people and observed behavior. The results of the study that after analyzing the learning process with the discoveri method were very helpful for lecturers in creating an active, educative and enjoyable learning atmosphere and could stimulate students to think critically and creatively in finding independent learning resources.
\end{abstract}

Keywords: Gandoang Site, Discoveri learning learning

\section{PENDAHULUAN}

Mahasiswa merupakan kaum intelek yang harus memiliki keterampilan berfikir kritis. Untuk itu dosen/pendidik harus memiliki kreativitas dalam setiap pembelajaran di kelas dalam memicu kemampuan mahasiswanya. Belajar dan pembelajaran merupakan usaha perubahan seseorang yang tidak tahu menjadi tahu, usaha merubah tingkah laku seseorang, usaha merubah pola fikir seseorang dan usaha menumbuhkan kreatifitas seseorang. Dalam usaha melakukan perubahan tersebut maka perlu adanya metode atau cara dalam setiap proses pembelajaran supaya tujuan yang di inginkan tercapai.

\footnotetext{
${ }^{1}$ Penulis Koresponden

E-mail address: wulansondarika13@gmail.com doi: $10.25157 /$ ja.v6i1.2047
}

Menurut Nurholis (2019: 41) upaya untuk menciptakan pendidikan yang berkualitas diantaranya dengan menciptakan pembelajaran yang kreatif, inspiratif dan menyenangkan, sehingga siswa dapat berperan aktif dalam pembelajaran.

Untuk mencapai tujuan pembelajaran tersebut tidaklah mudah. Tidak jarang banyak rintangan yang harus di hadapi oleh seorang dosen ketika sedang proses belajar mengajar contohnya banyak mahasiswa yang tidak konsentrasi dalam materi yang sedang di bahas. Untuk itu dosen perlu melakukan metode yang inovatif dalam pembelajaran yang dapat memicu mahasiswa aktif untuk belajar.

Metode adalah suatu cara yang dipergunakan untuk mencapai tujuan yang telah

Copyright@2019 Jurnal Artefak e-ISSN: 2580-0027 
ditetapkan. Dalam kegiatan belajar mengajar, metode diperlukan oleh pendidik/dosen dan penggunaannya bervariasi sesuai tujuan yang ingin di capai setelah pembelajaran berakhir. Seorang pendidik/dosen tidak akan dapat melaksanakan tugasnya bila dia tidak menguasai satupun metode pembelajaran yang telah dirumuskan para ahli psikologi dan pendidikan (Edi Abdullah, 2016:55).

Metode pembelajaran di gunakan selain untuk tercapainya tujuan pembelajaran juga untuk menginformasikan kepada mahasiswa program studi pendidikan sejarah yang secara umum tujuan capaian lulusannya yaitu sebagai seorang guru sejarah, bawasannya diharapkan setiap kali meakukan proses belajar mengajar dihimbau untuk menggunakan metode atau model pembelajaran. Disini peneliti memperkenalkan metode pembelajaran kepada mahsiswa sekaligus mempraktekkan metode pembelajaran tersebut dalam sebuah PBM. Dikarenakan kondisi pembelajaran sejarah di SMA sangat jauh dari harapan, ini terbukti dengan minat baca pada pelajaran sejarah SMA sangat rendah. Hal ini merupakan dampak dari proses belajar mengajar guru sejarah di SMA yang selalu menggunakan metode konvensional, yaitu metode ceramah yang dapat membuat bosan peserta didik dalam belajar. Untuk itu peneliti berusaha keras dalam memperkenalkan metode atau model pembelajaran sejarah kepada mahasiswa keguruan supaya kelak mereka menggunakannya dimasa yang akan datang. Sehingga tujuan pembelajaran sejarah akan tercapai dengan baik.

Salah satu metode pembelajaran yang dianggap sesuai untuk mahasiswa yaitu dengan menggunakan model discovery learning. Dalam pembelajaran dengan menggunakan pendekatan discovery learning ini, pendidik/dosen harus menempatkan peserta didik sebagai subjek dan objek dalam belajar, dan harus dipandang sebagai stimulus yang dapat menantang siswa untuk melakukan kegiatan belajar. Dengan kata lain mahasiswa lebih banyak melakukan kegiatan belajar sendiri dan pendidik/dosen menempatkan diri sebagai pembimbing atau fasilitator.

Nunuk dan Leo (2012: 25) menjelaskan bahwa pendekatan Discovery merupakan pendekatan mengajar yang berusaha meletakan dasar dan mengembangkan cara berfikir ilmiah. pendekatan ini menempatkan peserta didik lebih banyaklebih banyak belajar sendiri, mengembangkan keaktifan dalam memecahkan masalah. siswa betul-betul ditempatkan sebagai subjek yang belajar. Peranan pendidik dalam metode Discovery adalah pembimbing belajar dan fasilitator belajar. Tugas utama pendidik/dosen adalah memilih masalah yang perlu di lontarkan kepada kelas untuk dipecahkan oleh siswa sendiri. Tugas berikutnya dari pendidik adalah menyediakan sumber belajar bagi siswa dalam rangka pemecahan masalah.

Metode discovery dalam pembelajaran sejarah dengan tema situs Gandoang sebagai media pembelajaran bertujuan untuk melatih mahasiswa dalam menganalisis suatu peristiwa masa lampau dan manfaat situs Gandoang sebagai sumber belajar sejarah dan pariwisata lokal. Dengan metode ini paneliti berharap tujuan tersebut dapat tercapai dengan baik. Selain itu juga dengan metode discovery dapat merangsang mahasiswa untuk berfikir kritis dan kreatif dalam mencari sumber belajar dari berbagai macam sumber yang tersedia.

\section{METODE PENELITIAN}

Bentuk metode penelitian dalam penelitian ini yaitu kualitatif. Penelitian kualitatif adalah prosedur penelitian yang menghasilkan data deskriptif berupa kata-kata tertulis atau lisan dari orang-orang dan perilaku yang diamati. Penelitian kualitatif adalah penelitian yang bermaksud untuk memahami fenomena tentang apa yang dialami oleh subjek penelitian, misalnya perilaku, persepsi, motivasi, tindakan, dan lain-lain secara holistik dan dengan cara deskriptif dalam bentuk kata-kata dan bahasa, pada suatu konteks khusus yang dialami dengan memanfaatkan berbagai metode alamiah (Moleong, 2006: 6).

Dalam rangka kepentingan pengumpulan data, teknik yang digunakan diantaranya; observasi, wawancara dan studi dokumentasi.

1. Observasi adalah teknik pengumpulan data dengan melakukan pengamatan langsung terhadap subjek (partner penelitian) dimana sehari-hari mereka berada dan biasa melakukan aktifitasnya. pemanfaatan teknologi informasi menjadi ujung tombak kegiatan observasi yang dilaksanakan seperti pemanfaatan situs Gandoang dalam pembelajaran sejarah.

2. Wawancara yang dilakukan adalah untuk memperoleh makna yang rasional, maka observasi perlu dikuatkan dengan 
wawancara. Wawancara merupakan teknik pengumpulan data dengan melakukan dialog langsung dengan sumber daya dan dilakukan dengan carat berstuktur, dimana responden mendapatkan kebebasan dan kesempatan untuk mengeluarkan pikiran, pandangan, dan perasaan secara natural. Dalam proses wawancara ini di dokumentasikan dalam bentuk catatan tertulis dan Audio visual, hal ini dilakukan untuk meningkatkan kebernilaian dari data yang diperoleh.

3. Studi dokumentasi. Selain sumber manusia (human resources) melalui observasi dan wawancara sumber lainnya sebagai pendukung yaitu dokumen tertuulis yang resmi ataupun tidak resmi (Asep Suryana, 2007: 7).

\section{HASIL PENELITIAN DAN PEMBAHASAN}

\section{Hasil Penelitian}

Sejarah Situs Gandoang

Peninggalan Kerajaan Galuh di Ciamis yang berupa tinggalan arkeologis antara lain Situs Astana Gede di Kawali, Situs Karangkamulyan, Situs Gunung Padang Cikoneng, Situs Gunung Susuru, Situs Patilasan Sanghyang Cipta Permana Parbu Digaluh di Cimaragas, dan Situs Nagara Pageuh di Panawangan (Lubis, dkk 2013:88-131). Selain yang disebutkan di atas, ternyata di Sindangkasih terdapat Situs Gandoang yang didalamnya ada makam dan naskah-naskah kuno.

Makam yang ada di situs Gandoang tersebut diyakini sebagai makam tokoh desa tersebut yang menyebarkan Islam dan juga mendirikan desa tersebut/desa Wanasigra. Sedangkan naskah kuno berisi tentang penugasan sultan Mataram terhadap Mas Putu Imbanagara untuk memimpin Galuh. Naskah lain menyebutkan adanya sebuah perselisihan antara adipati Kusumadinata dengan Raden Rangga Pingpisan dari Wanasigra, yang diharapkan jangan sampai memanas (wawancara dengan bapak Yudi tanggal 29 Februari 2017).

Di desa Wanasigra terdapat beberapa peninggalan arkeologis antara lain; naskah tambaga wanasigra, naskah daluang gandoang, tombak, keris dan makam syeh Padamatang, makam mas Jasidin, makam eyang Bodas, dan makan santri/ muris dari syeh Padamatang (wawancara dengan kuncen setempat tanggal 29 Februari 2017).
Naskah tambaga Wanasigra berbahan dari lempengan tembaga berwarna kekuningan berukuran $28 \mathrm{~cm}$ x $5 \mathrm{~cm}$ x $0,2 \mathrm{~cm}$. Ruang tulisan $26 \times 3,5 \mathrm{~cm}$. Tulisan tersebut menggunakan bahasa Jawa kuno dan aksara cacarakan bentuk karangan prosa hurufnya ditulis bolak balik dengan cara digurat dengan memakai jara. Selanjutnya yaitu naskah Kabuyutan Gandoang yang terbuat dari daun daluang berbentuk pipih memanjang yang sudah berwarna kecoklatan. Naskah Gandoang ini diprediksi ditulis oleh beberapa orang karena terbukti di dalam teks tidak terdapat judul. Bahasa di dalam teks tersebut menggunakan bahasa dan aksara Jawa kuno. Isinya menceritakan tentang surat yang ditulis oleh Susuhuna Senopati Ing Ngalaga kepada Mas Putu atau Mas Putra Imbanagara agar mempimpin Galuh. Di dalam naskah tersebut dijelaskan waktu penulisannya yaitu tertanggal 22 Maret 1635 hari kamis bulan syawal tahun $\mathrm{He}$ (Zaenudin dalam Yadi Kusmayadi, 2018: 39).

Secara ilmiah, naskah-naskah kuno tersebut masih harus digali dan dikritisi dengan sumber lain yang lebih valid. Karena kita ketahui bahwa sumber sejarah yang sifatnya tradisional lebih banyak mengandung unsur subyektivitas dibanding obyektivitasnya. Walau bagaimanapun, naskah kuno tersebut adalah peninggalan yang harus kita lestarikan.

Selanjutnya yaitu peninggalan berupa makam atau kuburan yang di keramatkan oleh masyarakat setempat karena dianggap sebagai penyebar agama Islam di daerah Galuh dan ini dipercai sebagai makam embah Wanasigra atau Syeh Padamatang, yang terletak di sisi sungai Cigayam Wanasigra, lalu makam Syeh mbah Azibun di tepi sungai Cigayam Kampung Cisaray dan makam Syeh Mbah Sarikasih di Gunung Asih, Pucak Asih. Selain itu juga terdapat makam Mas Jasidin (yang dipercayai sebagai murid sekaligus penerus Syeh Padamatan), makam Eyang Bodas (pengawal/ajudan) lalu makam santri-santri Syeh Padamatan. Makam-makam tersebut dikelilingi oleh batu-batu yang berjajar rapi menghimpun, dan menurut informasi batu-batu tersebut merupakan tempat duduk santri-santri Syeh Padamatan ketika sedang mendengarkan ceramah Syeh Padamatan. Menurut masyarakat Wanasigra bahwa cerita Syeh Padamatang dimulai sejak tahun 1677 dengan membuka pemukiman atau perkampungan di Wanasigra selain itu juga Syeh Padamatang merupakan penyebar agama Islam. Pada suatu hari ketika 
Syeh Padamatang melakukan syukuran khitanan putranya yang bernama Yuda Perwira, dan anak tersebut memakai pakaian tenun hitam yang dicelup ke dalam nila hitam tiba-tiba menghilang. Lalu di ketemukan sudah menjadi mayat di sumur dekat kandang kerbau. Kemudian ada keributan yang mengakibatkan kerbau ngamuk dan memakan korban jiwa, tiga orang meninggal akibat amukan kerbau tersebut. Setelah peristiwa yang menyedihkan tersebut lalu Syeh Padamatang mengeluarkan pantangan, yaitu dilarang menanggap hiburan yang waditranya terdapat goong besar kemudian tidak boleh menyembelih kerbau ketika hajatan dan tidak boleh membuat sumur bundar dengan anyaman bambu di atasnya selain itu juga pengantin sunan dilarang memakai baju tenun hitam. Radea dalam Yadi Kusmayadi (2018: 39)

\section{Pemanfaatan Situs Gandoang Dalam Pembelajaran Dengan Metode Discovery Learning}

\section{Hasil Observasi}

Dari hasil observasi pertama yang dilakukan pada tanggal 27 Februari 2017, sekitar pukul 08.40 mata kuliah Belajar dan Pembelajaran Sejarah dimulai. Dosen mulai menyiapkan kondisi kelas, berdoa dan dosen menanyakan bakar dari semua mahasiswa. Selanjutnya dosen mengabsen mahasiswa dan menanyakan apakah ada mahasiswa yang tidak hadir? kemudian dosen mulai mengulas lagi pembahasan minggu lalu. Setelah itu baru perkuliahan dimulai dengan menggunakan metode ceramah dalam pembahasan "Macammacam Metode Dalam Pembelajaran Sejarah" terlihat dengan jelas, tidak ada keantusiasan mahasiswa dalam mengikuti proses belajar di kelas. Hal ini dikarenakan ada dua kemungkinan, yang pertama adalah metode dosen yang tidak menarik dalam pembelajaran yaitu hanya dengan menggunakan metode konvensional yaitu ceramah, yang kedua yaitu pembahasan atau materi yang kurang menarik yang menjadikan mahasiswa malas untuk belajar macam-macam metode pembelajaran.

Dosen berusaha menjelaskan dengan sebaik-baiknya mengenai materi macam-macam metode dalam pembelajaran sejarah, namun hanya satu sampai dua orang yang mengajukan pertanyaan dan menjawab pertanyaan dosen, yang lainnya hanya menyimak saja dan terlihat tidak kooperatif.

Setelah melihat kondisi mahasiswa yang tidak kooperatif dalam pembelajaran, maka dosen berinisiatif untuk melakukan pembelajaran di luar kelas dengan menggunakan metode discovery learning. Pembelajaran rencananya akan dilakukan pada pertemuan selanjutnya di situs Gandoang yang terletak di desa Wanasigra Kec. Cikoneng Kabupaten Ciamis.

Sebelum pembelajaran di akhiri, dosen membagi kelompok. Dalam dua kelas yang berjumlah 23 mahasiswa dosen membagi menjadi lima kelompok. Masing-masing kelompok memiliki tugasnya yang akan di pimpin oleh satu orang ketua, satu orang sekretaris dan satu orang lagi sebagai anggota.

Dosen membagi materi pada setiap kelompok, diantaranya yaitu kelompok satu membahas meteri tentang situs, kelompok dua membahas tentang materi sejarah situs gandoang, kelompok tiga membahas tentang naskah situs Gandoang, kelompok empat membahas tentang materi potensi wisata situs Gandoang, materi ke lima membahas tentang kesadaran masyarakat sekitar akan keberadaan situs. Setelah itu kemudian dosen mengakhiri perkuliahan dengan doa dan salam.

Observasi kedua dilaksanakan pada tanggal 3 Maret 2017. Sesuai dengan rencana pada minggu lalu bahwa pembelajaarn akan dilakukan di luar kelas dengan menggunakan metode discovery guna untuk melatih mahasiswa dalam berfikir kritis dan melatih mahasiswa dalam mencari sumber yang akurat.

Dari kampus mahasiswa beserta dosen pengampu berangkat pada pukul 07.00 WIB dan sampai di lokasi situs Gandoang pada pukul 07.30 WIB. Sebelumnya dosen sudah meminta izin pada kuncen setempat untuk kunjungan pada tanggal 3 Maret 2017 dan kuncen tersebut mengizinkannya kami untuk melakukan penelitian di lokasi tersebut.

Setelah sesampainya ditempat tujuan yaitu di situs Gandoang, maka kami langsung menemui kuncen dan langsung ke dalam atau ke lokasi inti. Mahasiswa langsung berhimpun dengan kelompoknya masing-masing dan mulai mempelajari materi yang sudah diberikan dosen. Lalu ketua kelompok masing-masing secara sikap memberikan tugas pada masing-masing anggotanya untuk mewawancari kuncen, aparat desa setempat dan masyarakat tentang situs Gandoang dan potensi wisatanya.

Setelah mahasiswa selesai mengamati dan mewawancarai narasumber, mahasiswa diajak untuk menanam tanaman sebagai pengganti pohon-pohon yang sudah tumbang dan berumur 


\section{Wulan Sondarika}

Pemanfaatan Situs Gandoang Dalam Pembelajaran Dengan Metode Discoveri Learning

Pada Mahasiswa Program Studi Pendidikan Sejarah

tua di lokasi situs tersebut. Setelah kegiatan menanam pohon siswa melakukan operasi semut (bersih-bersih), terhadap sampah-sampah daun yang berguguran. Setelah itu kegiatan dilajutkan dengan acara makan siang dilanjutkan ramah tamah dengan kuncen, aparat desa dan masyarakat setempat. Dalam acara ramah tamah itu, terjadi dialog antara mahasiswa, dosen, kuncen, pejabat desa Wanasigra dan masyarakat terutama berkaitan tentang sejarah situs Wanasigra dan naskah kuno. Dalam dialog itu terungkap kesimpulan dari mahasiswa bahwa dilihat dari sisi historis tentang keberadaan situs Wanasigra. Disamping itu mitos masyarakat dan hal-hal yang bersifat tabu sesungguhnya berorientasi semata-mata untuk menjaga hutan agar tetap lestari dan terjaga ekosistemnya.

Setelah makan siang selesai kemudian dosen beserta mahasiswa kembali ke kampus untuk melanjutnya pembelajaran pada mata kuliah selanjutnya.

Observasi ketiga tanggal 9 Maret 2017 pada kesempatan ini materi yang dibahas mengenai hasil kunjungan ke situs Gandoang di Desa Wanasigra Kab. Ciamis dosen mengucap salam dan menanyakan kabar para mahasiswa, semua mahasiswa menjawab salam "waalaikum salam, baik bu". Kemudian dosen memulai dengan bismillah dilanjutkan dengan mengabsen mahasiswa. Selanjutnya guru mengingatkan agar pada saat perkuliahan berlangsung mahasiswa dilarang melakukan aktivitas lain diluar pembelajaran.

Pada bagian apersepsi, dosen bertanya jawab dengan mahasiswa mengenai materi sebelumnya. Dalam kesempatan itu dosen bertanya: Apakah menurut kalian terdapat hubungan antara Kerajaan Galuh dengan situs Gandoang? mahasiswa yang bernama Faisal menjawab: "ada hubungannya yaitu dibuktikan dengan periodesasi dari kerajaan Galuh dan dihubungkan dengan naskah kuno Gandoang".

Pada perkuliahan ini dosen menggunakan metode diskusi. Materi yang di diskusikan yaitu hasil dari pembelajaran dengan menggunakan metode discovery pada pertemuan minggu lalu. Pada pertemuan selanjutnya, hasil temuan dilapangan pada minggu lalu di presentasikan kemuan di diskusikan di kelas.

Kelompok satu mendapatkan giliran pertama untuk mempresentasikan penemuannya pada minggu lalu di situs Gandoang, kemudian di anjutkan dengan kelompok dua, dilanjutkan lagi dengan kelompok tiga, empat dan lima.
Kelompok pertama mempresentasikan mengenai pengertian Situs. Penjelasannya situs merupakan tempat yang memiliki peninggalan arkeologi dan di dalamnya terdapat peninggalan artefak, fitur dan ekofak. Kemudian dilanjutkan dengan penjelasan kelompok dua yaitu mengenai sejarah situs gandoang. Tahun 1677 Syeh Padamatang merupakan pemimpin di Wanasigra sekaligus penyebar agama Islam.

Kelompok ketika mempresentasikan materi tentang naskah situs Gandoang, Di situs Gandoang memiliki beberapa peninggalan arkeologis yang dapat menggambarkan peristiwa masa lampau di daerah Galuh. Diantaranya yaitu Naskah Tambaga Wanasigra yang terbuat dari lempengan tembaga berwarna kekuningan bertuliskan bahasa Jawa Kuno. Naskah kedua yaitu Naskah Kabuyutan Gandoang yang terbuat dari kertas Daluwang. Tulisan di dalamnya menggunakan bahasa Jawa dan aksara Jawa. Isi teks naskah menceritakan tentang surat yang dituliskan oleh Susuhunan Senapati Ing Ngalaga kepada Mas Putu atau Mas Putra Imbanagara agar menduduki, memangku dan mengurusi Galuh.

Kelompok empat membahas tentang materi potensi wisata situs Gandoang. Mahasiswa menjelakan bahwasannya Situs Gandoang pada dasarnya memiliki potensi wisata apabila ada kemauan dari masyarakat dan pemerintahan terkait. Upaya untuk memperkenalkan situs Gandoang ke khalayak ramai dapat dilakukan dengan beberapa cara, diantaranya yaitu mempublikasikannya ke media online seperti google atau media sosial. Selain itu juga bisa diperkenalkan melalui penunjuk arah supaya masyarakat yang melintas melalui jalur Cikoneng dapat melihatnya dan sebagainya.

Materi ke lima membahas tentang kesadaran masyarakat sekitar akan keberadaan situs Gandoang. Hasil obsevasi yang ditemukan dilapangan yaitu bahwa masyarakat Wanasigra kurang sadar akan manfaat situs kesejarahan. Untuk itu perlu ada pendampingan dari pemerintahan atau isntitusi terkait seperti dinas pariwisata dalam pengemasan wisata sejarah di Wanasigra.

Setelah di analisis proses pembelajaran dengan metode discoveri sangat membantu dosen dalam menciptakan suasana belajar yang aktif, edukatif dan menyenangkan serta dapat merangsang siswa untuk berfikir kritis dan kreatif dalam mencari sumber belajar mandiri. 


\section{PENUTUP}

\section{Simpulan}

Dari hasil observasi pertama perkuliahan dimulai dengan menggunakan metode ceramah dalam pembahasan "Macam-macam Metode Dalam Pembelajaran Sejarah" terlihat dengan jelas, tidak ada keantusiasan mahasiswa dalam mengikuti proses belajar di kelas.

Observasi kedua dilaksanakan pada tanggal 3 Maret 2017. Sesuai dengan rencana bahwa pembelajaarn akan dilakukan di luar kelas dengan menggunakan metode discovery. Lalu ketua kelompok masing-masing secara sikap memberikan tugas pada masing-masing anggotanya untuk mewawancari kuncen, aparat desa setempat dan masyarakat tentang situs Gandoang dan potensi wisatanya.

Observasi ketiga tanggal 9 Maret 2017 pada kesempatan ini materi yang dibahas mengenai hasil kunjungan ke situs Gandoang di Desa Wanasigra Kab. Pada perkuliahan ini dosen menggunakan metode diskusi. Kelompok pertama mempresentasikan mengenai pengertian Situs. Kemudian dilanjutkan dengan penjelasan kelompok dua yaitu mengenai sejarah situs gandoang. Kelompok ketika mempresentasikan materi tentang naskah situs Gandoang. Kelompok empat membahas tentang materi potensi wisata situs Gandoang. Materi ke lima membahas tentang kesadaran masyarakat sekitar akan keberadaan situs Gandoang. Setelah di analisis proses pembelajaran dengan metode discoveri sangat membantu dosen dalam menciptakan suasana belajar yang aktif, edukatif dan menyenangkan serta dapat merangsang siswa untuk berfikir kritis dan kreatif dalam mencari sumber belajar mandiri.

\section{DAFTAR PUSTAKA}

Abdullah, Edi. (2016). Penerapan Metode Discovery Untuk Meningkatkan Prestasi Belajar Mata Pelajaran Proses Pengolahan Dan Pengawetan Siswa Kelas X Smk Negeri 2 Pinrang. Jurnal Pendidikan Teknologi Pertanian. Vol 2, 51-61.

Kusmayadi, Yadi. (2018). Pengembangan Potensi Wisata Situs Gandoang Wanasigra Untuk Meningkatkan Kesejahteraan Ekonomi Masyarakat Desa Wanasigra Kecamatan Sindangkasih Kabupaten Ciamis. Serang: Jurnal
Candrasangkala. vol. 4 No. 1. ISSN: 2477-8214 Hal: 31-47

Lubis, Nina Herlina, dkk. (2013). Sejarah Kerajaan Sunda. Bandung: Yayasan MSI.

Moleong, Lexy. 2006. Metodologi Penelitian Kualitatif. Bandung: Remaja Rosda Karya.

Nunuk dan Leo. (2012) Strategi Belajar Mengajar. Yogyakarta. Ombak.

Nurholis, Egi. (2019). Karakter Dan Sikap Disiplin Mahasiswa Tingkat I Prodi Pendidikan Sejarah Di Universitas Galuh Ciamis. Prosidding UPI "Profesionalisme Guru Dalam Membangun Karakter Bangsa Dan Mengokohkan Nkri" Bandung: IKA IPAI Press: ISBN: 978623-7083-01-6 Hal 41-51

Suryana, Asep. 2007. Tahap-tahap Penelitian Kualitatif Mata Kuliah Analisis Data Kualitatif . 